\title{
An Approach to Impart Bactericidal Effect to Viscose Fabric Using Ionic Liquids
}

\author{
A. A. El-Sayed, A. Kantouch and H. El-Sayed \\ Textile Research Division, National Research Centre, Cairo, \\ Egypt.
}

\begin{abstract}
7 HE ANIONIC agent (AA) dichloro triazinyl amino benzene sulphonate was prepared and applied to viscose fabrics. The pretreated fabrics were then treated with selected ionic liquids (ILs); namely 1-butyl 3-methyl imidazolium bromide (BMIB), 1-butyl 3methyl imidazolium chloride (BMIC), 1-ethyl 3-methyl imidazolium acetate (EMIA) and 1-ethyl 3-methyl imidazolium ethyl sulphate (EMIES). Viscose fabrics treated with AA/IL system has shown excellent bacterial resistance to gram +ve and gram -ve bacteria when properly treated with the selected ionic liquid. The substantivity of the cationic agent to viscose fabric and hence the bactericidal effect, increase in the order BMIB>BMIC>EMIES $>$ EMIA. Marvelous durability of the treated fabrics was observed after 10 washing cycles of the treated fabrics. Infrared spectroscopy as well as nitrogen content of the untreated as well as treated viscose fabrics was conducted to ensure strong and permanent fixation of both the anionic agent and the ionic liquids to the viscose fabrics.
\end{abstract}

Keywords: Viscose, Ionic liquids, Antibacterial, Triazine and Imidazolium .

The competitiveness of viscose is sustained by solid demand for regenerated fibres to meet customer preferences. Viscose is the most important and widely used regenerated fabrics. Nevertheless, the growth of bacteria on viscose is one of its inherent properties, which results in cross-infection by pathogens, development of odour, staining and loss in fibre strength. Consequently, application of substances of bactericidal nature is necessary to obtain viscosebased medical textiles and odour-free sport wear.

In the last three decades, the increase in the number of microbially-induced diseases and hospital infections has led to intensive research onto new materials and procedures, which would guarantee permanent bioactive effects together with complete safety for the users ${ }^{(1-3)}$.

Modification of cellulose-based fibres for medical applications may be classified into four methods ${ }^{(4-6)}$ : (i) oxidation procedures, (ii) synthesis of antimicrobial cellulose, (iii) incorporation of metallic nanoparticles and iv) various coating strategies at the finishing stages using quaternary ammonium compounds ${ }^{(7,8)}$. Chitin and its derivate chitosan, is currently popular for antimicrobial treatment of cellulose- 
based fibres. Chitosan offers many advantages over traditional cotton and regenerated cellulose fibres treatments because of its non-toxicity, biodegradability and biocompatibility $^{(9)}$. A domestic drug, Viz. poly hexamethylene guanidine hydrochloride, was also examined to impart antimicrobial effect to viscose fabrics ${ }^{(10)}$.

So far and up to our knowledge, no practically verified antibacterial methods for viscose fabrics using ionic liquids have been reported. In this investigation, a novel approach has been conducted to increase the resistance of viscose fabrics to Escherichia coli $(\mathrm{G}-\mathrm{ve})$ and Staphylococcus aurous $(\mathrm{G}+\mathrm{ve})$ bacteria using ionic liquids as greener chemicals. The anionic agent dichloro triazinyl $\rho$-amino benzene sulphonate was used to create enough anionic sites on viscose fabrics. Accordingly, the ionic liquid with cationic nature was anchored permanently to the modified viscose fabric via strong salt linkages.

\section{Materials}

\section{Experimental}

Plain weave scoured unfinished $100 \%$ viscose fabric was supplied from Abou El-Ola for Spinning and Weaving, 10 $0^{\text {th }}$ of Ramadan, Egypt. Weight of fabric was 110 $\mathrm{g} / \mathrm{m}^{2}$, its number of ends was $375 / 10 \mathrm{~cm}$ and number of weft was $320 / 10 \mathrm{~cm}$.

\section{Chemicals}

2,4,6-trichlro,1,3,5- triazine and 4-amino benzene sulphonic acid were from Aldrich, Steinheim, Germany. 1-Butyl 3-methyl imidazolium bromide (BMIB) and 1-butyl 3-methyl imidazolium chloride (BMIC) were supplied by Merck, Chemicals, Germany. 1-Ethyl 3-methyl imidazolium acetate (EMIA) and 1-ethyl 3-methyl imidazolium Ethyl sulphate (EMIES) were provided by IoLiTec Ionic Liquids Technologies, Stuttgart, Germany. Egyptol PLM, a nonionic detergent based on nonyl phenol ethoxylate, was kindly supplied from Starch and Detergent Company, Alexandria, Egypt. Other chemicals are of laboratory grade and used without any further purification.

\section{Methods}

Synthesis of the anionic agent

A solution of the sodium salt of 4-amino benzene sulphonic acid (SABSA) was prepared by dissolving $1 \mathrm{gm}\left(5.7 \times 10^{-3}\right.$ mole $)$ of 4 -amino benzene sulphonic acid and $0.34 \mathrm{gm}\left(3.2 \times 10^{-3}\right.$ mole $)$ of sodium carbonate in $10 \mathrm{ml}$ distilled water.

A solution of 2,4,6-trichlro 1,3,5- triazine (TCTA) was prepared by dissolving $1.1 \mathrm{gm}(0.06$ mole $)$ of TCTA in $10 \mathrm{ml}$ acetone. The $\mathrm{pH}$ of this solution was adjusted at $\mathrm{pH} 2$ and cooled to below $0-5{ }^{\circ} \mathrm{C}$.

Solutions of SABSA and TCTA were mixed with continuous stirring. The $\mathrm{pH}$ value of the reaction mixture was raised to $\mathrm{pH} 6$ using $1.0 \mathrm{M}$ sodium carbonate solution. The reaction is left to continue for $1 \mathrm{hr}$ at $0{ }^{\circ} \mathrm{C}$ with stirring. A white precipitate of the anionic agent (mechanism shown below), dichloro triazinyl amino benzene sulphonate, is formed, filtered, washed thoroughly with acetone and air-dried. The yield percent of the salt was $72 \%$.

Egypt. J. Chem. 54, No.4 (2011) 

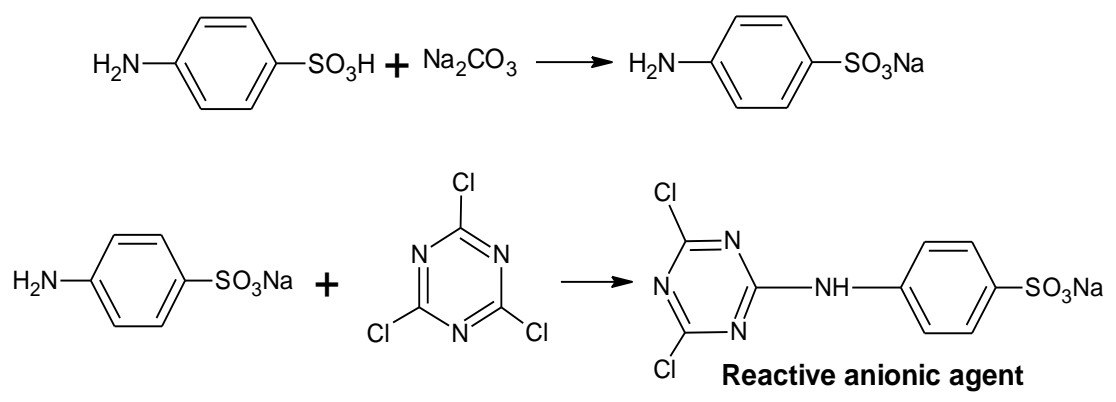

Chart I

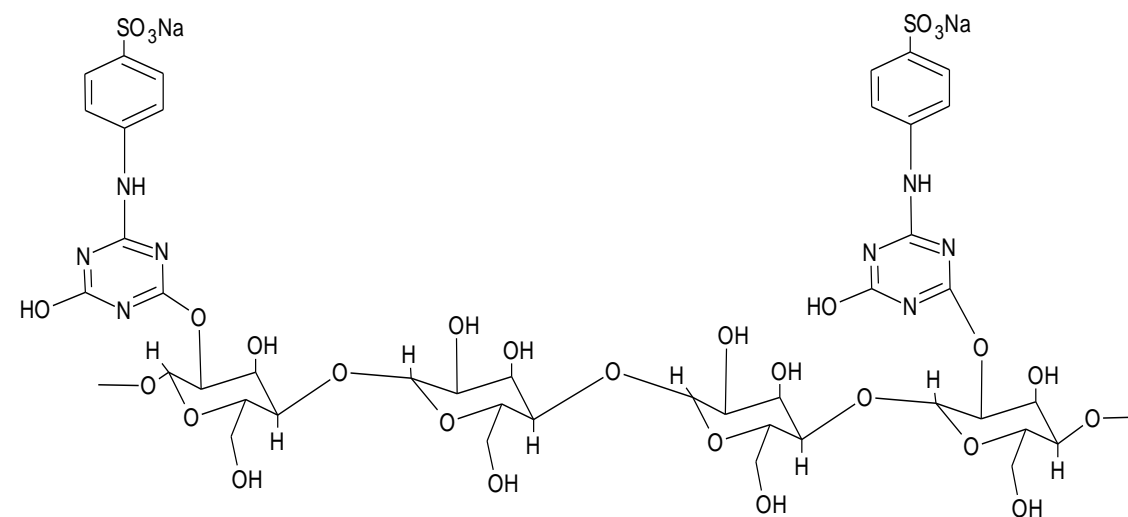

Viscose fabric treated with reactive anionic agent Chart II

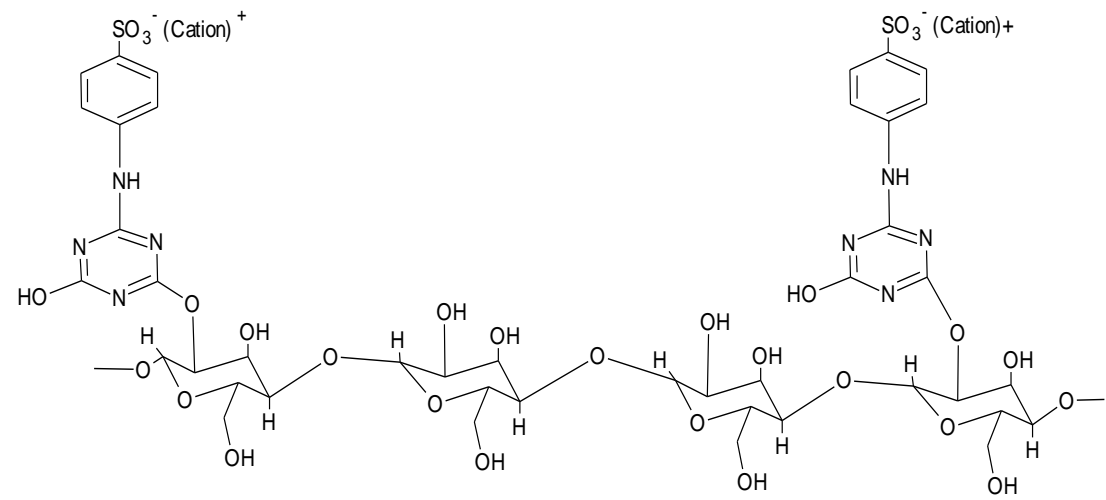

Viscose fabric treated with reactive anionic agent and ionic liquids (Cationic agent)

Chart III

Egypt. J. Chem. 54, No.4 (2011) 
Treatment of viscose fabrics

Scoured viscose fabrics were pretreated with different amounts of the prepared reactive anionic agent water solution for $1 \mathrm{hr}$ at $40-70{ }^{\circ} \mathrm{C}$ and $\mathrm{pH}$ values $7-10$.

The pretreated viscose fabric $(1 \mathrm{~g})$ was, after treating with $100 \mathrm{ml}$ aqueous solution of the ionic liquid, BMIB, BMIC, EMIA, or EMIES of different concentrations for $1 \mathrm{hr}$ at different temperature, thoroughly rinsed in water several times to remove the unbounded chemicals and dried at room temperature.

The amount of the anionic agent as well as that of the ionic liquids consumed by viscose fabric was assessed spectrophotometrically using JENWAY spectrophotometer $6405 \mathrm{UV} / \mathrm{Vis}$, UK by measuring the residual concentrations of these reagents in the treatment bath at their respective lambda maxima.

\section{Bacterial analyses}

The antibacterial properties were quantitatively evaluated (Bacterial Count) according to the AATCC test method 100-1999. Two species of bacteria were used; namely Escherichia coli AATCC 2666 (G-ve) and Staphylococcus aurous AATCC $6538(\mathrm{G}+\mathrm{ve})$. Bacteria reduction was calculated as follows:

$$
\text { Reduction percentage }(\%)=\frac{\mathrm{A}-\mathrm{B}}{\mathrm{A}} \times 100
$$

A

where: A and B are the number of colonies of bacteria on the untreated and treated fabrics; respectively.

\section{Washing fastness}

The washing durability test method for the treated fabrics was assessed according to the AATCC test method 61 - 1989. One gram sample is soaked in $40 \mathrm{ml}$ solution containing $2 \mathrm{~g} / \mathrm{l}$ Egyptol PLM. Washing was conducted at $40{ }^{\circ} \mathrm{C}$ for $20 \mathrm{~min}$.

\section{Nitrogen content}

The nitrogen content of the untreated as well as the treated viscose samples before and after washing was determined by the elemental analyzer (Elemental Analysensystem, GmbH, Vario EL III, Germany).

\section{Infra red spectroscopy}

Samples of trichloro trazine, $\rho$-amino benzene sulphonic acid, and dichloro triazinyle $\rho$-amino benzene sulphonic acid were analysed by IR spectroscopy, using a Nicolet 60 SXR Fourier transform infrared spectrometer, in the attenuated total reflection mode with a KRS5 crystal.

Egypt. J. Chem. 54, No.4 (2011) 


\section{Results and Discussion}

The major problem encountered to anchor a cationic antibacterial agent to cellulosic fabric is its lack of attractive anionic sites. Aiming to overcome this problem, the reactive anionic agent dichloro triazinyl-p-amino benzene sulphonate was synthesized and utilized as a bridge compound for the cationic ionic liquid.

The anionic reagent dichloro triazinyl $\rho$-amino benzene sulphonate was prepared by the method of Son et al. ${ }^{(11)}$. Figure 1 shows the FTIR spectra of 1,3,5-trichloro 2,4,6-trazine (chart I), $\rho$-amino benzene sulphonic acid (chart II), and dichloro triazinyle $\rho$-amino benzene sulphonic acid (chart III).

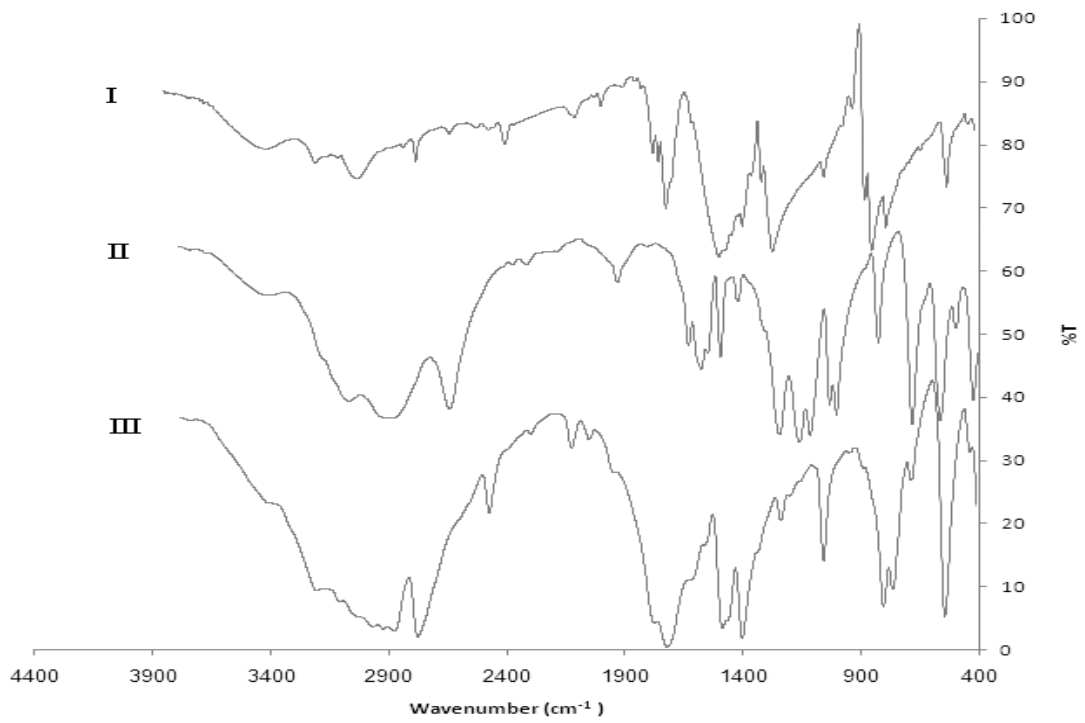

Fig. 1. FTIR spectra of trichloro trazine (I), $\rho$-amino benzene sulphonic acid (II) and dichloro triazinyle $\rho$-amino benzene sulphonic acid (III).

Chart I reveals the $\mathrm{C}=\mathrm{N}$ stretching vibration of a conjugated cyclic system at $1497 \mathrm{~cm}^{-1}$, which is the main moiety in 1,3,5-trichloro 2,4,6-trazine (sample I). In chart II, the $\mathrm{N}-\mathrm{H}$ stretching vibration band of the primary amino group appears as a medium doublet bands at 3070 and $2882 \mathrm{~cm}^{-1}$. Chart III elucidates a single weak band appears around $3000 \mathrm{~cm}^{-1}$ which corresponds to the $\mathrm{N}-\mathrm{H}$ stretching vibration band in secondary amines.

Effect of reaction conditions on the amount of anionic agent taken by viscose fabrics

Viscose fabrics were treated with aqueous solution of the prepared anionic agent using various reaction conditions. The reactive anionic agent is fixed to the viscose fabric through its reactive triazinyl group with the hydroxyl group of

Egypt. J. Chem. 54, No.4 (2011) 
viscose, via a covalent bound. The residual amount of the anionic agent in the treatment bath was determined spectrophotometrically, and so the amount taken by the fabrics was determined by subtraction.

The effect of AA concentration, $\mathrm{pH}$ value, and temperature of the treatment bath on the substantivity of the anionic agent to viscose fabrics was studied. Results of this investigation, shown in Tables 1-3, clarify that as the amount of AA taken by the fabric increased, when the amount of the AA taken by viscose fabric is increased. Also, the \% exhaustion was found to be $70 \%$ whatever be the concentration of the AA used.

On the other hand, the amount of anionic agent taken by viscose fabric in slightly alkaline medium $(\mathrm{pH} 8)$ is nearly threefold that taken by the same mass of viscose fabrics in neutral medium. In alkaline medium, the hydroxyl groups in viscose fibres are in the ionized state and can be more accessible to react with a halogen atom of the anionic agent. Further increase in the $\mathrm{pH}$ of the treatment bath from 8 to 10 has no remarkable effect on the substantivety of viscose towards the used anionic agent.

TABLE 1. Effect of anionic agent concentration on its amount of taken by $1 \mathrm{~g}$ viscose fabrics (treatment conditions: $1 \mathrm{hr}, 50^{\circ} \mathrm{C}, \mathrm{pH}: 8$ ).

\begin{tabular}{|c|c|c|c|c|}
\hline \multirow{2}{*}{$\begin{array}{c}\text { Conc. of AA } \\
\text { g/100g fabric }\end{array}$} & \multicolumn{2}{|c|}{$\begin{array}{c}\text { Measured concentration of anionic } \\
\text { agent in the treatment bath } \\
(\mathbf{g} / \mathbf{1 0 0 0 m l})\end{array}$} & \multicolumn{2}{c|}{$\begin{array}{c}\text { Amount of anionic agent } \\
\text { taken by the fabric }\end{array}$} \\
\cline { 2 - 5 } & $\begin{array}{c}\text { Before } \\
\text { treatment }\end{array}$ & $\begin{array}{c}\text { Remaining in } \\
\text { treatment bath }\end{array}$ & g/100 g fabric & $\begin{array}{c}\text { Exhaustion } \\
(\%)\end{array}$ \\
\hline 0.60 & 0.69 & 0.21 & 0.48 & 69.6 \\
\hline 0.9 & 1.11 & 0.375 & 0.73 & 66.2 \\
\hline 1.2 & 1.26 & 0.402 & 0.85 & 68.0 \\
\hline 1.5 & 1.74 & 0.537 & 1.20 & 69.1 \\
\hline
\end{tabular}

TABLE 2. Effect of pH of treatment bath on the amount of anionic agent reacted with viscose fabrics (treatment conditions: $1 \mathrm{hr}, 50^{\circ} \mathrm{C}$ ).

\begin{tabular}{|c|c|c|c|c|}
\hline \multirow{2}{*}{$\mathbf{p H}$} & \multicolumn{2}{|c|}{$\begin{array}{c}\text { Concentration of anionic agent in the } \\
\text { treatment bath } \mathbf{( g / 1 0 0 0} \mathbf{~ m l})\end{array}$} & \multicolumn{2}{|c|}{$\begin{array}{c}\text { Amount of anionic agent } \\
\text { taken by the fabric }\end{array}$} \\
\cline { 2 - 5 } & $\begin{array}{c}\text { Before } \\
\text { treatment }\end{array}$ & $\begin{array}{c}\text { Remaining in the } \\
\text { treatment bath }\end{array}$ & $\begin{array}{c}\text { g/100 g } \\
\text { fabric }\end{array}$ & $\begin{array}{c}\text { Exhaustion } \\
(\%)\end{array}$ \\
\hline 7 & 1.74 & 1.218 & 0.52 & 30.0 \\
\hline 8 & 1.74 & 0.537 & 1.20 & 69.1 \\
\hline 9 & 1.74 & 0.486 & 1.25 & 72.0 \\
\hline 10 & 1.74 & 0.468 & 1.27 & 73.1 \\
\hline
\end{tabular}

Egypt. J. Chem. 54, No.4 (2011) 
Similar trend was encountered upon increasing the reaction temperature from $40^{\circ} \mathrm{C}$ up to $70^{\circ} \mathrm{C}$. Sixty percent of the anionic agent is taken by the fabric at $40^{\circ} \mathrm{C}$, compared to $72 \%$ at $50^{\circ} \mathrm{C}$. Further increase in the reaction temperature resulted in no change in the amount of anionic agent taken by viscose fabrics.

TABLE 3. Effect of temperature of the treatment bath on the amount of anionic agent reacted with viscose fabrics (treatment conditions: 1 hr, pH 9).

\begin{tabular}{|c|c|c|c|c|}
\hline \multirow{2}{*}{$\begin{array}{c}\text { Temperature } \\
\left({ }^{\circ} \mathbf{C}\right)\end{array}$} & \multicolumn{2}{|c|}{$\begin{array}{c}\text { Concentration of anionic agent in } \\
\text { the treatment bath }(\mathbf{g} / \mathbf{1 0 0 0} \mathbf{~ m l})\end{array}$} & \multicolumn{2}{|c|}{$\begin{array}{c}\text { Amount of anionic agent } \\
\text { taken by the fabric }\end{array}$} \\
\cline { 2 - 5 } & $\begin{array}{c}\text { Before } \\
\text { treatment }\end{array}$ & $\begin{array}{c}\text { Remaining after } \\
\text { treatment }\end{array}$ & $\begin{array}{c}\text { g/100 g } \\
\text { fabric }\end{array}$ & $\begin{array}{c}\text { Exhaustion } \\
(\%)\end{array}$ \\
\hline 40 & 1.74 & 0.696 & 1.04 & 60.0 \\
\hline 50 & 1.74 & 0.486 & 1.25 & 72.0 \\
\hline 60 & 1.74 & 0.522 & 1.22 & 70.0 \\
\hline 70 & 1.74 & 0.506 & 1.23 & 70.9 \\
\hline
\end{tabular}

Effect of ionic liquid concentration on its amount absorbed by viscose fabric

The anionic agent pretreated, as well as, the untreated viscose fabrics were treated with different amounts of the ionic liquids BMIC, BMIB, EMIES and EMIA. The amount of the IL taken by viscose fabric was determined spectrophotometrically and the number of moles of IL taken by $1 \mathrm{~g}$ pretreated as well as untreated viscose fabrics was calculated. This treatment would result in formation of a salt link between the sulphonic group of the anionic agent, fixed on the pretreated viscose fabrics and the quaternary nitrogen (cationic sites) of the IL. This reaction depends on the strength of the basisty of the cationic group of the ionic liquids .

The effect of the molar ratio IL/AA on the amount of IL fixed by viscose fabric was investigated. Results of this study, summarized in Table 4, show that in all cases, the amount of IL taken by viscose fabrics pretreated with the AA is much higher than that taken by untreated fabrics. Data of this table reveal also that the amount of IL taken by pretreated viscose samples varies significantly depending on the used IL in the order BMIC $\approx \mathrm{BMIB}>$ EMIES>EMIA. It seems also that the substantivity of viscose fabrics towards the IL depends on its polarity as well as the length of the side chain at $\mathrm{C}_{1}$ of the imidazolium ring; both in a direct relationship. BMIC and BMIB are polar compounds having 4 carbon atoms at $\mathrm{C}_{1}$ of the imidazolium ring; EMIES is polar but has shorter carbon chain, and EMIA has lower polarity and shorter carbon side-chain. 
TABLE 4. Effect of ionic liquid(IL)/anionic agent (AA) molar ratio on the amount of IL absorbed by viscose fabrics. (1 $\mathrm{g}$ viscose fabric was soaked in $100 \mathrm{ml} \mathrm{IL}$ solution at room temperature for $1 \mathrm{hr}$ ).

\begin{tabular}{|c|c|c|c|c|c|}
\hline \multirow{2}{*}{ IL } & \multirow{2}{*}{$\begin{array}{c}\text { IL/AA } \\
\text { molar ratio }\end{array}$} & \multicolumn{2}{|c|}{$\begin{array}{l}\text { Concentration of IL in the } \\
\text { treatment bath }(\mathrm{g} / 1000 \mathrm{ml})\end{array}$} & \multicolumn{2}{|c|}{$\begin{array}{c}\text { Amount of IL taken } \\
\text { by the fabric }\end{array}$} \\
\hline & & $\begin{array}{c}\text { Before } \\
\text { treatment }\end{array}$ & $\begin{array}{c}\text { After } \\
\text { treatment }\end{array}$ & $\begin{array}{l}\mathrm{g} / 100 \mathrm{~g} \\
\text { fabric }\end{array}$ & $(\%)$ \\
\hline \multirow{4}{*}{ BMIC } & Only IL & 1.044 & 0.985 & 0.059 & 5.65 \\
\hline & $0.5: 1$ & 0.261 & 0.0 & 0.261 & 100 \\
\hline & $1: 1$ & 0.522 & 0.051 & 0.471 & 90.23 \\
\hline & $2: 1$ & 1.044 & 0.477 & 0.567 & 54.3 \\
\hline \multirow{4}{*}{ BMIB } & Only IL & 1.314 & 1.233 & 0.081 & 4.6 \\
\hline & $0.5: 1$ & 0.327 & 0.0 & 0.327 & 100 \\
\hline & $1: 1$ & 0.657 & 0.045 & 0.612 & 92.7 \\
\hline & $2: 1$ & 1.314 & 0.600 & 0.714 & 52.5 \\
\hline \multirow{4}{*}{ EMIES } & Only IL & 1.41 & 1.353 & 0.057 & 3.8 \\
\hline & $0.5: 1$ & 0.351 & 0.150 & 0.201 & 57.0 \\
\hline & $1: 1$ & 0.705 & 0.484 & 0.221 & 31.3 \\
\hline & $2: 1$ & 1.41 & 1.16 & 0.25 & 17.7 \\
\hline \multirow{4}{*}{ EMIA } & Only IL & 1.188 & 1.152 & 0.036 & 3.0 \\
\hline & $0.5: 1$ & 0.297 & 0.133 & 0.164 & 54.8 \\
\hline & $1: 1$ & 0.594 & 0.421 & 0.173 & 29.1 \\
\hline & $2: 1$ & 1.188 & 0.994 & 0.194 & 16.3 \\
\hline
\end{tabular}

Effect of treatment of viscose with $A A / I L$ system at room temperature on its antibacterial properties

Tables 5 and 6 summarize the bactericidal effect imparted to viscose fabric after being pre-treated with anionic agent followed by aftertreatment with the ionic liquid BMIB, BMIC, EMIA, or EMIES at room temperature. Investigation of these tables indicates the following:

- Untreated viscose fabrics has no resistance to the bacterial attack, while those pretreated with the AA has very limited resistance to both Escherichia coli (gram -ve) and Staphylococcus aureus (gram $+\mathrm{ve})$.

- The resistance of AA-pretreated viscose fabric to bacterial attack is enhanced remarkably after being treated with the IL to different extents depending on the concentration of the IL. Maximum bactericidal effect was attained in case of viscose fabrics treated with BMIB amounting to $0.714 \mathrm{~g} / 100 \mathrm{~g}$ fabric. The least resistant viscose fabrics are those treated with $0.163 \mathrm{~g}$ EMIA/100 g fabric. The bactericidal effect of the used ILs is attributed to their cationic nature which enables them to interact with the anionic cell membrane of bacteria and neutralizes its electric charge. Alteration of the electric nature of the cell membrane of bacteria results in loss of its permeability and hence death of bacteria ${ }^{(12)}$.

Egypt. J. Chem. 54, No.4 (2011) 
- Investigation of these tables clarifies that, irrespective of the counter ion of the IL, the higher the amount of IL taken to the fabric, the higher is its resistance to bacteria.

- The antibacterial property of viscose fabrics decreased remarkably after 5 and 10 washing cycles. This implies that the bond formed between the IL and viscose is not strong enough to withstand the action of washing.

- For the same IL and concentration, the resistance of viscose-treated fabrics towards gram +ve is more than gram -ve bacteria; a result which is in harmony with many previous investigations ${ }^{(13-15)}$.

Effect of ionic liquid treatment temperature on the extent of antibacterial properties of the treated viscose fabrics

In order to fortify the bonds formed between the pretreated viscose fabric and the IL, the pretreated viscose fabric was after-treatment with the IL at $80^{\circ} \mathrm{C}$ for $1 \mathrm{hr}$. These conditions resemble those of the cationic dyeing which ensures durable bonding between the IL and the anionic agents fixed on of viscose fabrics.

Results of this experiment, abridged in Table 7, show that, the high resistance of viscose treated fabrics to both gram +ve and gram -ve, is not affected by repeated washing until 10 washing cycles. Comparing the results of this table with those in Tables 5 and 6 implies that increasing the treatment temperature results in stronger salt links between the anionic agent moiety on the viscose fabric and the cationic IL.

TABLE 5. Antimicrobial activity of viscose fabric treated with anionic agent (AA) followed by treatment with ionic liquid (IL) at room temperature against Escherichia coli (Gram-ve).

\begin{tabular}{|c|c|c|c|c|}
\hline \multirow[b]{2}{*}{ Treatment } & \multirow[b]{2}{*}{$\begin{array}{c}\text { Conc. of IL } \\
\text { (g/100 g fabric) }\end{array}$} & \multicolumn{3}{|c|}{ Reduction percent after } \\
\hline & & $\begin{array}{c}1 \text { washing } \\
\text { cycle }\end{array}$ & $\begin{array}{c}5 \text { washing } \\
\text { cycle }\end{array}$ & $\begin{array}{l}10 \text { washing } \\
\text { cycle }\end{array}$ \\
\hline Untreated & -- & Nil & Nil & Nil \\
\hline AA & -- & Nil & Nil & Nil \\
\hline \multirow{3}{*}{ AA/BMIC } & 0.261 & 40 & 40 & 33 \\
\hline & 0.471 & 88 & 87 & 60 \\
\hline & 0.567 & 92 & 92 & 79 \\
\hline \multirow{3}{*}{ AA/BMIB } & 0.327 & 42 & 40 & 35 \\
\hline & 0.612 & 94 & 91 & 71 \\
\hline & 0.714 & 99 & 94 & 86 \\
\hline \multirow{3}{*}{ AA/EMIES } & 0.201 & 32 & Nil & Nil \\
\hline & 0.221 & 36 & 27 & Nil \\
\hline & 0.25 & 45 & 39 & Nil \\
\hline \multirow{3}{*}{ AA/EMIA } & 0.164 & 27 & Nil & Nil \\
\hline & 0.173 & 27 & Nil & Nil \\
\hline & 0.194 & 39 & Nil & Nil \\
\hline
\end{tabular}


TABLE 6. Antimicrobial activity of viscose fabric treated with anionic agent (AA) followed by treatment with ionic liquid (IL) at room temperature against Staphylococcus aureus $(\mathrm{G}+\mathrm{ve})$.

\begin{tabular}{|l|c|c|c|c|}
\hline \multirow{3}{*}{ Ionic liquid } & \multirow{2}{*}{$\begin{array}{c}\text { Conc. of IL } \\
\text { (g/100 g fabric) }\end{array}$} & \multicolumn{3}{|c|}{ Reduction percent after } \\
\cline { 2 - 5 } & & $\begin{array}{c}\text { 1 washing } \\
\text { cycle }\end{array}$ & $\begin{array}{c}\mathbf{5} \text { washing } \\
\text { cycle }\end{array}$ & $\begin{array}{c}\text { 10 washing } \\
\text { cycle }\end{array}$ \\
\hline \multirow{3}{*}{ AA/BMIC } & 0.261 & 44 & 44 & 40 \\
\cline { 2 - 5 } & 0.468 & 90 & 89 & 66 \\
\hline \multirow{3}{*}{ AA/BMIB } & 0.567 & 99 & 90 & 83 \\
\cline { 2 - 5 } & 0.327 & 47 & 41 & 37 \\
\hline \multirow{3}{*}{ AA/EMIES } & 0.612 & 100 & 92 & 77 \\
\cline { 2 - 5 } & 0.714 & 100 & 96 & 90 \\
\cline { 2 - 5 } & 0.200 & 33 & Nil & Nil \\
\hline \multirow{3}{*}{ AA/EMIA } & 0.221 & 36 & 32 & Nil \\
\cline { 2 - 5 } & 0.250 & 30 & 41 & Nil \\
\cline { 2 - 5 } & 0.163 & 32 & Nil & Nil \\
\hline
\end{tabular}

TABLE 7. Antibacterial properties of viscose fabrics treated with AA/IL (Treatment conditions: AA/IL molar ratio $1: 1,80{ }^{\circ} \mathrm{C}$ for $1 \mathrm{hr}$ ).

\begin{tabular}{|l|c|c|c|c|}
\hline \multirow{2}{*}{$\begin{array}{c}\text { Conc. of ionic } \\
\text { liquid (g/100 } \\
\text { fabric) }\end{array}$} & \multicolumn{2}{|c|}{ Gram -ve } & \multicolumn{2}{c|}{ Reduction percent } \\
\cline { 2 - 5 } & $\begin{array}{c}\text { Before } \\
\text { washing }\end{array}$ & $\begin{array}{c}\text { After 10 } \\
\text { washing } \\
\text { cycle }\end{array}$ & $\begin{array}{c}\text { Before } \\
\text { washing }\end{array}$ & $\begin{array}{c}\text { After 10 } \\
\text { washing cycle }\end{array}$ \\
\hline BMIC (0.500) & 90 & 90 & 94 & 92 \\
\hline BMIB (0.630) & 97 & 96 & 100 & 98 \\
\hline EMIES (0.472) & 87 & 84 & 92 & 92 \\
\hline EMIA (0.402) & 83 & 80 & 90 & 90 \\
\hline
\end{tabular}

\section{Nitrogen content}

The nitrogen content has been taken as analytical tool to estimate the actual amount of nitrogen added to the fabrics after the modification with anionic agent and ionic liquids. Table 8 summarizes the nitrogen content of untreated as well as some of the treated viscose fabrics before and after 10 washing cycles. Data of this table reveal that the nitrogen content of the treated samples before washing range between $0.19-0.211 \%$, compared to $0.0 \%$ for the untreated sample. The nitrogen contents measurement of the treated fabrics after 10 washing cycles also shows minute decrease in the nitrogen content of the treated fabrics. This findings emphasize that the permanent treatment of viscose fabric with AA followed by IL, which is in harmony with the antibacterial results illustrated in Table 7.

Egypt. J. Chem. 54, No.4 (2011) 
TABLE 8. Nitrogen content of untreated as well as treated viscose fabrics after $\mathbf{1 0}$ washing cycle (Treatment conditions: concentration of AA was $1.5 \mathrm{~g} / \mathrm{g}$ fabric, $\mathrm{pH} 9$, temperature $50{ }^{\circ} \mathrm{C}$ for $1 \mathrm{hr}$; IL: AA/IL molar ratio $1: 1,80{ }^{\circ} \mathrm{C}$ for $1 \mathrm{hr}$ ).

\begin{tabular}{|l|c|c|}
\hline \multirow{2}{*}{ Sample } & \multicolumn{2}{|c|}{ Nitrogen content (\%) } \\
\cline { 2 - 3 } & Before washing & After 10 washing \\
\hline Untreated & 0.0 & Nil \\
\hline AA-treated fabric & 0.19 & 0.17 \\
\hline AA/BMIC-treated fabric & 0.26 & 0.24 \\
\hline AA/BMIB-treated fabric & 0.27 & 0.24 \\
\hline AA/EMIES-treated fabric & 0.218 & 0.193 \\
\hline AA/EMIA-treated fabric & 0.211 & 0.199 \\
\hline
\end{tabular}

\section{Conclusion}

The anionic agent (AA) dichloro triazinyl $\rho$-amino benzene sulphonate is a suitable candidate to crosslink some ionic liquids on viscose fabric. The ionic liquids (ILs) 1-butyl 3-methyl imidazolium bromide (BMIB), 1-butyl 3-methyl imidazolium chloride (BMIC), 1-ethyl 3-methyl imidazolium acetate (EMIA) and 1-ethyl 3-methyl imidazolium ethyl sulphate (EMIES) are used to render viscose fabrics bactericidal when appropriately linked to viscose fabrics. The efficiency of bonding to viscose fabric, and hence the antibacterial effect, increases in the order BMIB>BMIC>EMIES $>$ EMIA. Similar trend was encountered towards gram +ve and gram -ve bacteria.

The wash fastness tests for the antibacterial agent have shown that viscose fabrics treated with the AA/IL system is resistant to 10 washing cycles without decrease in the antibacterial properties. These results assure the durable bactericidal effect imparted to viscose fabrics by the aforementioned systems.

\section{References}

1. Chung, Y.S., Lee, K.K. and Kim, J.W., Durable press and antimicrobial finishing of cotton fabrics with a citric acid and chitosan treatment. Text. Res. J., 68 (10), 722 (1998) .

2. Liu, X.F., Guan, Y.L., Yang, D.Z., Li, Z. and Yao, K.D., Antibacterial action of chitosan and carboxymethylated chitosan. J. Appl. Polym. Sci. 79 (7), 1324-1335 (2000).

3. Lee, S., Cho, J.S. and Cho, G., Antimicrobial and blood repllent finishes for cotton and nonwoven fabrics based in chitosan and fluoropolymers. Text. Res. J., 69(2), 104 (1999) .

4. Gupta, D. and Bhaumik S., Antimicrobial treatments for textiles. Ind. J. Fib. Text. Res. 32(2), 254 (2007). 
5. Vigo, T.L., In: Biotechnology and Bioactive Polymers, C. Gebelein \& C. Carraher (Ed.), Plenum Press, New York (1994).

6. Vigo, T.L., Danna, G.F. and Goynes, W.K., Text. Chem. Color. 29 (1999).

7. Czaja, W., Krystynowicz, A. and Bielecki R.M., Sand brown, microbial cellulosethe natural power to heal wounds. J. Biomaterials, 27(2), 145(2006).

8. Rajendran, S., Anand, S.C. and Harrison, P.W., Developments in medical textiles: A critical appreciation of recent developments. Textile Progress, 32, 4 (2000).

9. Fras Zemljič, L., Strnad, S., Šauperl, O. and Stana-Kleinschek, K. , Characterization of amino groups for cotton fibers coated with chitosan. Text. Res. J. 79(3), 219 (2009).

10. Chapurina, M.A., Redna, L.V., Yudanuva, T.M., Khomyakov, K.P., Cherdyntsdeva, T.A. and Netrusov, A.I., Fibre Chemistry, 36(1), 30(2004).

11. Son, Y.A., Kim, B.Y., Ravikumar, K. and Lee,S.G., Imparting durable antimicrobial properties to cotton fabrics using quaternary ammonium salts through 4aminobenzenesulfonic acid-chloro-triazine adduct. Eur. Poly. J., 42, 3059(2006).

12. Ananthanarayan, R. and Paniker, C.K. J., Textbook of Microbiology, $6^{\text {th }}$ ed Orient Longman Limited, Hyderabad, India, 1 (2000).

13. Kantouch, A. and El-Sayed, A.A., Polyvinyl pyridine metal complex as permanent antimicrobial finishing for viscose fabric. Int. J. Biol. Macromol. 43, 451(2008).

14. Cho, J.S. and Cho, G., Effect of dual functional finish using antibiotics and fluorochemical on antimicrobial properties, blood repellency of surgical gown materials.Text. Res. J. 67(12), 875(1997).

15. Lee, S., Cho, J. S. and Cho, G., Antimicrobial and blood repellent finishes for cotton and nonwoven based on chitosan and fluoropolymers. Text. Res. J. 69(2), 104 (1999).

(Received 20/11/2011; accepted $15 / 1 / 2012$ ) 


\section{معالجة أقشة الفسكوز بالسوائل الأيونية لإكسابها مقاومة \\ للميكروبات \\ عمرو عاطف السيد ، عبد العذيذ محمد قنطوش و حسام الاين زكريا السيد

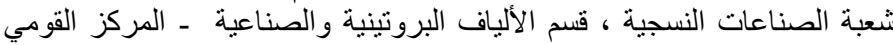

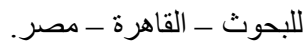

تهذف هذه الدراسة إلى إنتاج أقمشة فسكوز مقاومة للميكروبات باستخدام السوائل

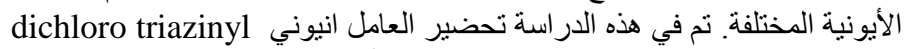
amino benzene sulphonate

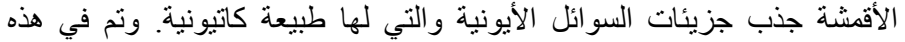

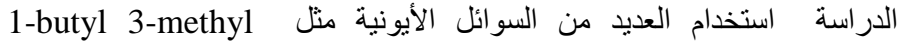
imidazolium bromide (BMIB), 1-butyl 3-methyl imidazolium chloride (BMIC), 1-ethyl 3-methyl imidazolium acetate (EMIA) and 1-ethyl 3-methyl imidazolium ethyl sulphate . (EMIES).

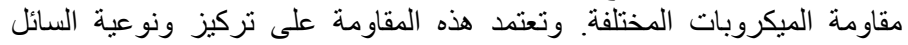

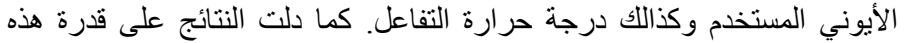

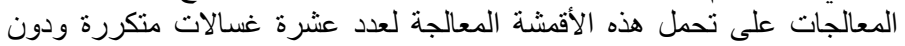

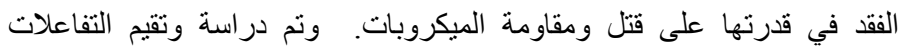

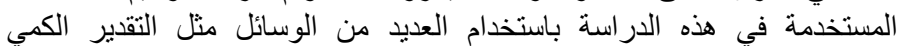
للنيتروجين و الآثُعة تحت لحمر اء و السبكتروفوتوميتر . 